\title{
Emerging disease of amphibians cured by elevated body temperature
}

\author{
Douglas C. Woodhams ${ }^{1, *}$, Ross A. Alford ${ }^{1}$, Gerry Marantelli ${ }^{2}$ \\ ${ }^{1}$ School of Tropical Biology, James Cook University, Townsville, Queensland 4811, Australia \\ ${ }^{2}$ Amphibian Research Centre, PO Box 424, Brunswick, Victoria 3056, Australia
}

\begin{abstract}
The emerging infectious disease chytridiomycosis is thought to have contributed to many of the recent alarming declines in amphibian populations. Mortalities associated with these declines have often occurred during cooler seasons and at high elevations, suggesting that environmental temperature may be an important factor in disease emergence. We found that thermal environment affects the progress of the disease, and that housing frogs Litoria chloris at an environmental temperature of $37^{\circ} \mathrm{C}$ for less than $16 \mathrm{~h}$ can clear them of the chytrid pathogen Batrachochytrium dendrobatidis. Our experiment demonstrated that elevated body temperatures similar to those experienced in behavioral fever and during normal thermoregulation can clear frogs of chytrid infection; therefore, variation in thermoregulatory opportunities and behaviors are likely to contribute to the differences in disease incidence observed among host species, populations, and regions. Although further refinement of the technique is needed to encompass various host species, appropriately applied thermal manipulations of amphibians and their enclosures may prove to be a safe and effective way of eliminating the fungal pathogen from captive amphibian populations and preventing accidental spread of the pathogen when animals are translocated or released from captivity.
\end{abstract}

KEY WORDS: Chytrid $\cdot$ Chytridiomycosis $\cdot$ Batrachochytrium dendrobatidis · Fungus - Amphibian · Cure - Temperature

Resale or republication not permitted without written consent of the publisher

Chytridiomycosis, caused by the amphibian chytrid fungus Batrachochytrium dendrobatidis, is an emerging infectious disease that is thought to have contributed to many of the recent alarming declines in amphibian populations (Berger et al. 1998, Daszak et al. 1999, Green et al. 2002). Mortalities associated with these declines have often occurred during cooler seasons and at high elevations (Berger et al. 1998, Bradley et al. 2002). This pattern, and the preference of $B$. dendrobatidis for cool conditions for growth in culture (Bradley et al. 2002), indicate that environmental temperature may be an important factor in disease emergence.
Environmental temperature may also be an important cofactor in disease treatment because of its influences on the immune function of ectotherms and the virulence of pathogens (Carey et al. 1999). For example, winter saprolegniosis in channel catfish was caused by low temperatures favoring pathogen growth and concurrent immunosuppression in catfish (Bly et al. 1993). Alternatively, many ectotherms exhibit behavioral fever in response to infection, leading to an enhanced host immune response, or perhaps reduced pathogenic activity (Kluger 1991). For some diseases, heat (or elevated body temperature) has the potential to be applied as a simple treatment or prophylaxis. Steck (1963) used elevated temperature in an experimental treatment of amoebic dysentery in reptiles. This may offer advantages over other forms of treatment; at least 2 clinical studies have had some success in treating chytridiomycosis with drugs (Nichols \& Lamirande $2001^{1}$, Parker et al. 2002), but the efficacy and risk of toxicity of drug-based treatments can be affected unpredictably by species identity and environmental interactions (Wright \& Whitaker 2001).

In culture, Batrachochytrium dendrobatidis can survive and grow at temperatures between 6 and $28^{\circ} \mathrm{C}$ (Bradley et al. 2002); the pathogen dies within $96 \mathrm{~h}$ at $32^{\circ} \mathrm{C}$, and within $4 \mathrm{~h}$ at $37^{\circ} \mathrm{C}$ (Berger 2001). The aim of our study was to investigate the thermal survival sensitivity of this pathogen in vivo and to evaluate the potential for manipulation of environmental temperature as an aid in treating chytridiomycosis in captive amphibians.

Materials and methods. We examined the patterns of survival over $94 \mathrm{~d}$ of infected and uninfected juve-

\footnotetext{
${ }^{1}$ Nichols DK, Lamirande EW (2001) Successful treatment of chytridiomycosis, 46; available at http://www2.open.ac.uk/ biology/froglog/
} 
nile frogs Litoria chloris (10 per treatment combination) in 4 thermal environments: (1) naturally fluctuating temperatures (range 13.5 to $23.2^{\circ} \mathrm{C}$ ) $;(2)$ constant $20^{\circ} \mathrm{C}_{i}$ (3) $8^{\circ} \mathrm{C}$ thermal variation; and (4) $37^{\circ} \mathrm{C}$ thermal variation (Fig. 1). Frogs in thermal variation treatments were maintained in the naturally fluctuating regime except for two $8 \mathrm{~h}$ periods (plus $1.5 \mathrm{~h}$ each for gradual warming or cooling) during which the frogs and their enclosures were placed in an environmental chamber at $37^{\circ} \mathrm{C}$ (Days 12 and 13 post-infection) or $8^{\circ} \mathrm{C}$ (Nights 12 and 13 post-infection). Infected frogs were given a standardized dose of $150 \mu \mathrm{l}$ of culture medium containing 15000 Batrachochytrium dendrobatidis zoospores and exposed for $15 \mathrm{~h}$ on Day 0 of the experiment, while uninfected frogs were sham-infected with sterile medium (Berger 2001). We determined infection status by histological examination of post-mortem skin samples (Berger et al. 2000).

Results. Of the uninfected frogs, all but 1 survived throughout the experiment. The survival patterns of infected frogs differed among temperature treatments (log rank test on censored survival data, $\mathrm{p}<0.0001$, Fig. 1). Frogs in the constant $20^{\circ} \mathrm{C}$ treatment survived for the shortest period, while those in the fluctuating and $8^{\circ} \mathrm{C}$ variation treatments survived longer. All frogs

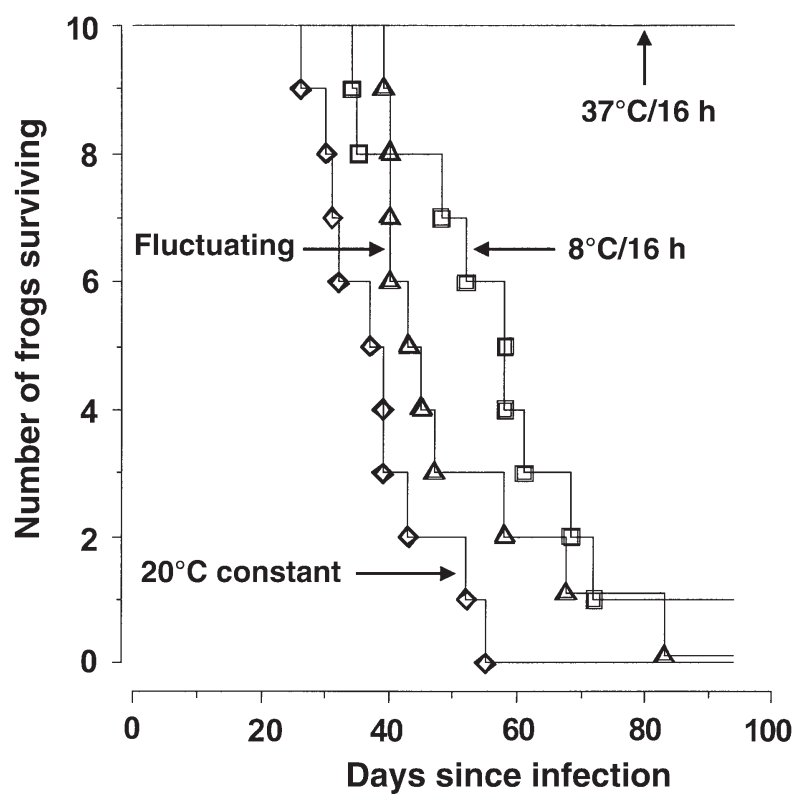

Fig. 1. Litoria chloris. Patterns of survival over $94 \mathrm{~d}$ of juveniles infected on Day 0 with the chytrid fungus Batrachochytrium dendrobatidis. Symbols represent individual frog mortalities. Each treatment was replicated on 20 individually housed frogs; half were infected with the pathogen while the other half (controls, omitted from figure) were sham-infected with sterile medium (Berger 2001) in these treatments were heavily infected with the pathogen, and only 1 individual survived to the termination of the experiment. All frogs in the $37^{\circ} \mathrm{C}$ variation treatment survived to the end of the experiment and for at least 5 mo after infection. Frogs that survived beyond termination of the experiment were humanely sacrificed using MS-222 anesthetic on Day 276 (9 mo after infection) to ensure containment of the disease. Histological examination of these frogs revealed no evidence of Batrachochytrium dendrobatidis; therefore, they were cured. All experimentation was carried out in accordance with Animal Ethics approval A699_01 from James Cook University, Australia.

Discussion. Our experiment demonstrated that the thermal regime affects the progress of chytridiomycosis in living frogs; low and fluctuating temperatures can retard the development of disease, and short periods of high body temperature can eliminate the pathogen from its hosts. Our data show that housing frogs at an environmental temperature of $37^{\circ} \mathrm{C}$ for less than $16 \mathrm{~h}$ can clear them of the pathogen and prevent the development of chytridiomycosis. It is possible that longer exposure to less elevated body temperatures would have similar effects; this should be tested with adult or larval hosts from temperate regions. Appropriately applied heat treatments may prove to be a safe and effective way of eliminating the fungal pathogen from captive amphibian populations and preventing accidental spread of the pathogen when animals are translocated or released from captivity.

It appears likely that high environmental temperatures, such as occur in tropical lowlands or in the summer months, may decrease the incidence of chytridiomycosis in amphibian populations, and may eliminate it entirely from some regions. This could partly explain the observed pattern of amphibian declines associated with chytridiomycosis that have tended to occur during cooler seasons and at high elevations (Berger et al. 1998, Bradley et al. 2002). Our experiment demonstrated that elevated body temperatures similar to those experienced in behavioral fever (Kluger 1991) and during normal thermoregulation (Hutchison \& Dupré 1992) can clear frogs of chytrid infection; therefore, variation in thermoregulatory opportunities and behaviors are likely to contribute to the differences in susceptibility observed among host species and populations (Berger et al. 1998, Alford \& Richards 1999).

Acknowledgements. The authors thank S. Townsend for histology, L. Berger and A. D. Hyatt of the Australian Animal Health Laboratories for supplying the chytrid culture, and volunteers of the Amphibian Research Centre. This project was supported by an IRCEB grant from the US National Science Foundation to R.A A. 


\section{LITERATURE CITED}

Alford RA, Richards SJ (1999) Global amphibian declines: a problem in applied ecology. Annu Rev Ecol Syst 30: 133-165

Berger L (2001) Diseases in Australian frogs. PhD thesis, James Cook University, Townsville

Berger L, Speare R, Daszak P, Green DE and 10 others (1998) Chytridiomycosis causes amphibian mortality associated with population declines in the rain forests of Australia and Central America. Proc Natl Acad Sci USA 95: 9031-9036

Berger L, Speare R, Kent A (2000) Diagnosis of chytridiomycosis in amphibians by histological examination. Zoos Print Journal 15:184-190

Bly JE, Lawson LA, Szalai AJ, Clem LW (1993) Environmental factors affecting outbreaks of winter saprolegniosis in channel catfish, Ictalurus punctatus (Rafinesque). J Fish Dis 16:541-549

Bradley GA, Rosen PC, Sredl MJ, Jones TR, Longcore JE (2002) Chytridiomycosis in native Arizona frogs. J Wildl Dis 38:206-212

Carey C, Cohen N, Rollins-Smith L (1999) Amphibian

Editorial responsibility: Peernel Zwart,

Utrecht, The Netherlands declines: an immunological perspective. Dev Comp Immunol 23:459-472

Daszak P, Berger L, Cunningham AA, Hyatt AD, Green DE, Speare R (1999) Emerging infectious diseases and amphibian population declines. Emerg Infect Dis 5(6):735-748

Green DE, Converse KA, Schrader AK (2002) Epizootiology of sixty-four amphibian morbidity and mortality events in the USA, 1996-2001. Ann NY Acad Sci 969:323-339

Hutchison VH, Dupré RK (1992) Thermoregulation. In: Feder ME, Burggren WW (eds) Environmental physiology of the amphibians. University of Chicago Press, Chicago, p 206-249

Kluger MJ (1991) Fever: role of pyrogens and cryogens. Physiol Rev 71:93-127

Parker JM, Mikaelian I, Hahn N, Diggs HE (2002) Clinical diagnosis and treatment of epidermal chytridiomycosis in African clawed frogs (Xenopus tropicalis). Comp Med 52:265-268

Steck F (1963) Die Amoebendysenterie der Reptilien. Acta Trop 20:115-142

Wright KM, Whitaker BR (2001) Pharmacotherapeutics. In: Wright KM, Whitaker BR (eds) Amphibian medicine and captive husbandry. Krieger Publishing, Malabar, FL, p 309-330

Submitted: October 8, 2002; Accepted: February 12, 2003

Proofs received from author(s): May 5, 2003 